\title{
Supply chain performance as a mediating variable effect of information technology on company competitiveness
}

\author{
Slamet Riyadi ${ }^{a^{*}}$, Musran Munizu ${ }^{\mathrm{b}}$ and Donny Arif ${ }^{\mathrm{c}}$
}

${ }^{a}$ Faculty of Economics and Business, Dr. Soetomo University, Surabaya, East Java Province, Indonesia

${ }^{b}$ Faculty of Economics and Business, Hasanuddin University, Makassar, South Sulawesi Province, Indonesia ${ }^{c}$ Universitas Maarif Hasyim Latif, Indonesia

\section{H R O N I C L E}

Article history:

Received March 12, 2021

Received in revised format May 8 , 2021

Accepted August 122021

Available online

August 122021

Keywords:

Information technology

Supply chain performance

Company competitiveness

Manufacturing Industry

\section{A B S T R A C T}

This study aims to analyze the effect of information technology on supply chain performance and information technology and supply chain performance on competitiveness. In addition, thisstudy also investigates the role of supply chain performance in indirectly mediating theinfluence of information technology on company competitiveness. Primary data collection wascarried out through questionnaires for managers of 112 manufacturing companies in East Javaand South Sulawesi, Indonesia. This study uses descriptive analysis to describe the characteristics of respondents and variables. In addition, structural equation modelling (SEM) analysis is also carried out to test the research hypothesis. The results showed that theimplementation of information technology has a positive and significant effect directly on supply chain performance and company competitiveness. Furthermore, supply chainperformance has a positive and significant effect on company competitiveness. In addition, supply chain performance has a positive role in mediating the influence of informationtechnology on company competitiveness.

\section{Introduction}

The manufacturing industry is one of the mainstay sectors that drive national economic growth. During the last ten years, the growth of the manufacturing industry in Indonesia has experienced a positive trend, namely in the range of 5.2-6.1\%. However, between 2019-2020, the business performance of this sector experienced a slowdown due to low production capacity and high production costs. In addition, there is a decrease in demand for products due to low consumer purchasing power and large-scale social restriction policies due to the Covid-19 pandemic, which directly limits consumer access to goods and services. This decline inperformance was also caused by lock-down policies by export destination countries thatdisrupted the supply chain system, marketing performance, and the competitiveness of companyproducts (Pono \& Munizu, 2021). Therefore, every company needs the right strategy to maintain its presence in the market and win the competition in a very dynamic market. Therefore, one of the important concepts in operations management, supply chain management(SCM), has been widely used by companies to improve competitiveness and performance (Pujawan \& Erawan, 2010; Prajogo \& Olhager, 2012; Basheer et al., 2019). Empirical facts have shown that the partnership between a company and its suppliers andcustomers is the key to winning the competition (Chopra \& Meindl, 2007; Qrunfleh \& Tarafdar,2014). Companies that have strong relationships with their partners will get higher benefits thancompetitors, mainly related to more efficient operating costs and higher company value (Kumaret al., 2017). The company can increase its partnerships in a supply chain system that is efficient and responsive to changing business environments. Efficient supply chain performance can beobserved through better connectivity between the company and its suppliers and customers, resulting in lower operating costs, short delivery times, low inventory levels, and increased company reliability in providing products to consumers (Heizer et al., 2017). The primary function of supply chain management is to increase the value and benefits obtained by all members through collaboration, cooperation, and information sharing, both in the short and long term. Therefore, the use of information technology can * Corresponding author

E-mail address: slamet.riyadi@, unitomo.ac.id (S. Riyadi)

(c) 2021 Growing Science Ltd. All rights reserved.

doi: $10.5267 /$ j.uscm.2021.8.008 
increase the degree of partnership between the company and all members of the supply chain system. The more efficient the supply chain, the higher the benefits that will be received by each member in the supply chain system, especially in improving organizational performance and competitiveness(S. Li et al., 2006; Yusuf \& Shehu, 2017). Advances in information technology have positively impacted company performance in the manufacturing, retail, and service sectors. Some of the concepts and models based on information technology are Material Requirement Planning (MRP), Enterprise Resource Planning (ERP), Electronic Data Interchange (EDI), and Decision Support System (DSS), Customer Relationship Management (CRM), and Supplier Relationships Management (SRM), which can accelerate the company's operational processes to improve product and service performance (Simchi-Levi et al., 2008; Bayraktar et al., 2009; Heizer et al., 2017).

The use of information technology in the context of supply chain management canimprove supply chain performance because the flow of information, money, and materials andthe performance of product delivery from the company to customers can be done quickly andon time. In addition, the use of information technology in business activities can strengthen thecompany's competitive strategy and company competitiveness ( $\mathrm{Li}$ et al., 2009; Huo et al., 2016).Information technology is one of the important factors that affect the competitiveness and performance of a company (NUGROHO et al., 2020). The intensity of the use of information technology in businessactivities can encourage increased competitiveness and company performance (S. Li \& Lin,2006). In the context of the supply chain system, the use of information technology can accelerate the flow of data and information from companies to suppliers and consumers, andvice versa (Iyer, 2011). Several previous studies have also proven that the use of informationtechnology can improve supply chain performance and company competitiveness (Rashed et al., 2010; Wang et al., 2016; Vanpoucke et al., 2017; Imran et al., 2019). Based on this description, it can be concluded that there are previous studies that have tested the direct effect of the use of information technology on supply chain performance and competitiveness (Nugroho et al., 2021). However, in the operational management literature, there have not been manytests on the effect of implementing information technology on company competitiveness indirectly mediated by supply chain performance variables. Therefore, the objective of this study is to examine theeffect of information technology on supply chain performance and company competitiveness, both directly and indirectly, in Indonesia's manufacturing industry.

\section{Literature review}

\subsection{Information technology}

Information technology advances very rapidly and is in line with the increasing needs of organizations in the current industrial 4.0 era. Information technology is concerned with a set of tools used to obtain, process, store, manipulate and present data and information to users. Information technology is not only limited to hardware and software but also includes the technology used to send data from within the company to the external environment (Lee \& Turban, 2001; Angeles, 2009). Several computer-based applications such as Enterprise Resources Planning (ERP), and Customer Relationships Management (CRM), Decision Support / Expert Systems (DSS), Electronic Data Interchange (EDI), e-business, e-commerce, and Bar Coding have been introduced, widely adopted, and implemented by companies to improve the quality of products and services to customers (Chopra \& Meindl, 2007; Heizer et al., 2017). The use of information technology can increase the productivity and value of the company. However, partially, the influence of information technology is greater on the creation of production process efficiency compared to other aspects such as marketing and customer satisfaction (Sohn \& Yang, 2006). In the context of supply chain management, the use of information technology can accelerate the exchange of information and data, including technology between partners in the supply chain system network. Several empirical studies have proven that the use of information technology can improve supply chain performance (G. Li et al., 2009; Lin et al., 2010; Iyer, 2011; Munir et al., 2020). In addition, the use of information technology can also increase company competitiveness (S. Li \& Lin, 2006; Ghobakhloo \& Tang, 2013; Wang et al., 2016). The information technology construct in this study is measured using five indicators, namely the intensity of the use of information technology applications, the use of EDI with suppliers, the use of EDI with customers, the use of DSS in strategic decision making, and the use of e-business technology in production and operation processes. These indicators are elaborated from research that was conducted by Li et al. (2009). Based on the results of a review of the existing literature, this study examines and confirms the consistency of the influence of information technology on supply chain performance and company competitiveness in the context of a manufacturing company. Therefore, the first and second hypotheses of this study are formulated as follows:

$\mathbf{H}_{1}$ : Intensive use of information technology improves supply chain performance.

$\mathbf{H}_{2}$ : Intensive use of information technology improves company competitiveness.

\subsection{Supply chain performance}

Supply chain management is a strategic concept and approach that emphasizes partnerships between companies and suppliers, factories, distributors in distributing products in the right quantity, location, and time to consumers or customers to make operational costs more efficient (Simchi-Levi et al., 2008). Conceptually, the supply chain is dynamic and involves three constant flows, namely information, products, and money. Supply chains that are managed efficiently will have an impact on increasing supply chain performance, competitiveness and company performance (Heizer et al., 2017). A supply chain system 
can be said to be effective if management as the manager and person in charge of the system can make suppliers as strategic partners of the company. Companies with a flexible and responsive supply chain system can immediately change market demand (Pujawan \& Erawan, 2010). Furthermore, several empirical studies have proven that the better the supply chain performance, the better the company's competitiveness (Gunasekaran et al., 2004; Akyuz \& Erkan, 2010; de Vass et al., 2018). Good supply chain performance makes product delivery to customers faster. The use of information technology in the context of supply chain management will accelerate the flow of information, money, and products to consumers in an efficient manner (Chopra \& Meindl, 2007). Every company can improve its supply chain performance through an integrated supply chain and information sharing supported by the intensive use of information technology within the company (Koçoğlu et al., 2011). This study uses five indicators in measuring the construct of supply chain performance, namely reliability, flexibility, utility, cost, and responsiveness. These indicators are developed from research conducted by Koçoğlu et al. (2011). Based on this description, the third and fourth hypotheses are formulated as follows:

H3: High supply chain performance increases the company's competitiveness.

$\mathbf{H}_{4}$ : Intensive use of information technology improves company competitiveness through the mediating role of supply chain performance variables.

\subsection{Company Competitiveness}

Company competitiveness is directly related to the process of creating corporate value. An organization or company can increase competitiveness through the optimal use of organizational resources and competencies. One way that can be done to increase the competitiveness of a company is to develop the capabilities and core competencies of the organization (Munizu, 2021). In addition, competitiveness is related to its ability to create a defensive position over its competitors. Thus, competitiveness consists of the abilities that make an organization different from its competitors. Competitiveness advantages can be achieved in various ways, including offering products at lower prices, offering unique and more specific products than competing products, or focusing on certain market segments (Porter, 2011). The concept of competitiveness has various interpretations and measures in the literature. For example, Li et al., (2006) measure competitiveness using indicators of cost, quality, delivery dependability, product innovation, and time to market. Meanwhile, Lakhal (2009) measures competitiveness using indicators of price, quality, time to market, and product innovation. Therefore, this study uses five indicators to measure the construct of company competitiveness: cost, product quality, operation flexibility, speed of delivery, and product innovation. Based on the literature review results, the conceptual model of this study is described in figure below.

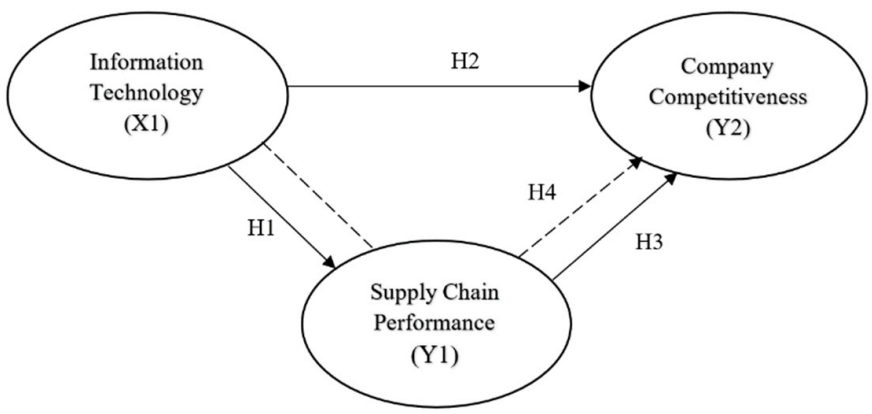

Fig. 1. Conceptual Framework Model

\section{Methodology}

This study used causality design as the primary approach. Relationships between variables that have been built in the model were conceptualized, hypothesized, and then testedempirically based on field data. The unit of research analysis was a medium and large-scale manufacturing company in Indonesia. Meanwhile, the research respondents were managers who represent their respective companies. This study uses a questionnaire as the main data collection tool. The primary data collection survey was conducted from January to February 2021. Data collection was carried out directly by researchers at the sample companies. There were 112 company units designated asresearch samples, 62 company units (55.36\%) were in East Java, and 50 company units $(44.64 \%)$ in South Sulawesi, Indonesia. In accordance with the conceptual research model, the information technology constructwas the exogenous variable, the supply chain performance construct was the endogenous variable-1 or mediating variable, and company competitiveness was an endogenous variable-2. Variable information technology consists of five indicators that adopted from Li et al. (2009), namely the intensity of the use of information technology applications, the use of EDI with suppliers, the use of EDI with customers, the use of DSS in strategic decision making, and theuse of ebusiness technology in production and operation processes. Then, the supply chain performance variable involves five indicators that developed from research that was conducted by Koçoğlu et al. (2011). These indicators consist of reliability, flexibility, utility, delivery cost, and responsiveness. Variable of company competitiveness adopted and elaborated from studies conducted by Li et al., (2006) and Lakhal (2009). This variable is measured by five indicators namely cost, product quality, operation flexibility, speed of delivery, and product innovation. Furthermore, respondents' perceptions of the indicators of each variable were measured using a Likert scale(1-5), namely: strongly disagree (1), disagree (2), 
neutral/doubt (3), agree (4), and strongly agree (5). Data were collected through questionnaires, interviews, and documentation. This study used a validity test questionnaire, Pearson product-moment correlation analysis and Cronbach's Alpha $(\alpha)$ reliability test. The results of testing the validity and reliability of the complete questionnaire are presented in the table below.

Table 1

Test Results of Validity and Reliability of Research Instruments

\begin{tabular}{|c|c|c|c|c|}
\hline Variables & Indicator & Correlation coefficient (r) & Alpha Cronbach $(\alpha)$ & Description \\
\hline \multirow{5}{*}{ Information technology } & $\mathrm{X} 1.1$ & 0.407 & \multirow{5}{*}{0.669} & \multirow{5}{*}{ Valid and Reliable } \\
\hline & $\mathrm{X} 1.2$ & 0.413 & & \\
\hline & $\mathrm{X} 1.3$ & 0.474 & & \\
\hline & $\mathrm{X} 1.4$ & 0.481 & & \\
\hline & $\mathrm{X} 1.5$ & 0.356 & & \\
\hline \multirow{5}{*}{ Supply chain performance } & Y1.1 & 0.33 & \multirow{5}{*}{0.688} & \multirow{5}{*}{ Valid and Reliable } \\
\hline & Y1.2 & 0.547 & & \\
\hline & Y1.3 & 0.542 & & \\
\hline & Y1.4 & 0.433 & & \\
\hline & Y1.5 & 0.376 & & \\
\hline \multirow{5}{*}{ Company competitiveness } & Y2.1 & 0.559 & \multirow{5}{*}{0.842} & \multirow{5}{*}{ Valid and Reliable } \\
\hline & Y 2.2 & 0.692 & & \\
\hline & Y2.3 & 0.626 & & \\
\hline & Y 2.4 & 0.751 & & \\
\hline & Y2.5 & 0.635 & & \\
\hline
\end{tabular}

Source: Data processed (2021)

Table 1 shows that all indicator variables used are valid because they have a correlation coefficient value $>0.30$. In addition, the variable in this study also has a high level of reliabilitybecause it has a Cronbach $\alpha$ value $>0.60$. According to Sugiyono (2018), an indicator can be said to be valid if the correlation coefficient value is more significant than 0.30. Furthermore, a variable can be said to be reliable if it has a Cronbach $\alpha$ value greater than 0.60 (Hair et al., 2014). Meanwhile, the analysis method used consisted of descriptive statistical analysis and structural equation modelling (SEM) analysis. Descriptive statistical analysis was used to describe the characteristics of respondents and variables, while SEM analysis was used to test the research hypothesis based on field data. Data processing was performed using IBM SPSS and AMOS 25 software.

\section{Empirical Results}

\subsection{Descriptive Statistical Analysis}

Descriptive statistical analysis was used to produce data and information that explains the characteristics of respondents, indicators, and research variables in the form of percentage values (\%) and average values (mean). In brief, a description of the characteristics of the respondents in this study can be seen in Fig. 2 as follows,

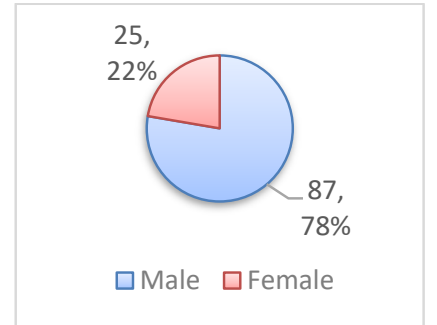

Gender

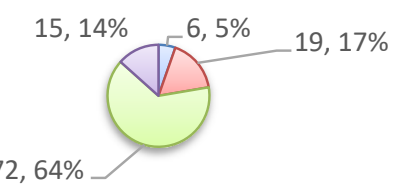

$\square$ Highschool

$\square$ Diploma (D1-D4)

$\square$ Undergraduate (S1) $\square$ Graduate (S2 \& S3)

Level of Education

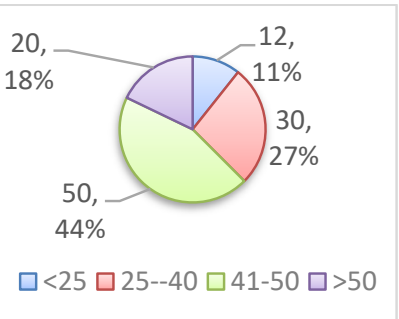

Age

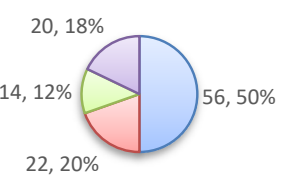

口Operations/Factory Manager $\square$ HRD Manager

$\square$ Marketing Manager asupervisor Position $9,8 \%$

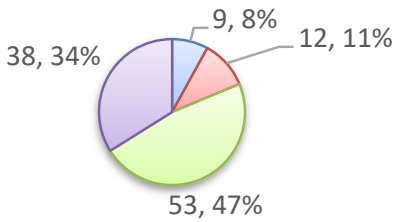

$\square<5 \quad \square 5--10 \quad \square 11--15 \quad \square 15--20$

Years of experience

Fig. 2. Personal characteristics of the participants 
Based on the data in Fig. 2, it can be explained that the research respondents were male, as many as 87 people (77.68\%), and female, as many as 25 people $(22.32 \%)$. Furthermore, theresearch respondents were dominated by the age of $41-50$ years old with a total of 50 people(44.64\%). Meanwhile, in terms of education level, respondents were dominated by undergraduate (16.96\%), followed by Diploma (D1-D4) with 19 people (16.96\%). Furthermore, most respondents have a duration of work for 11-20 years (47.32\%) and over 20 years $(33.93 \%)$ with the position of operational manager or factory manager (50\%), and as many as 22 resourcemanagers. (19.64\%). The rest of the respondents served as marketing managers and supervisors. Descriptive statistical analysis also produces data that describes the sample companyprofile, as can be seen in the Fig. 3 below.

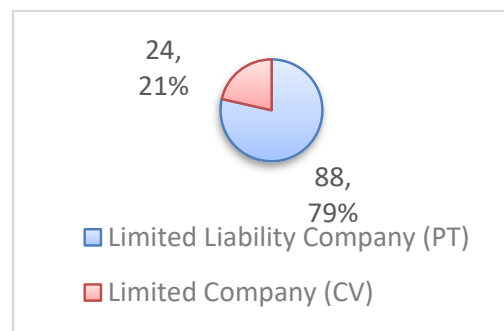

Company type

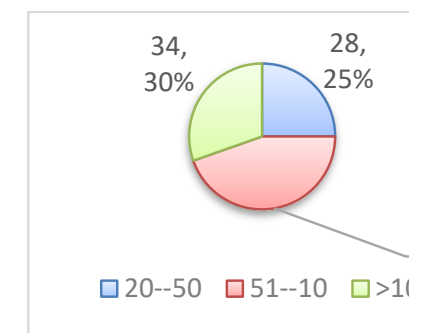

Workforce

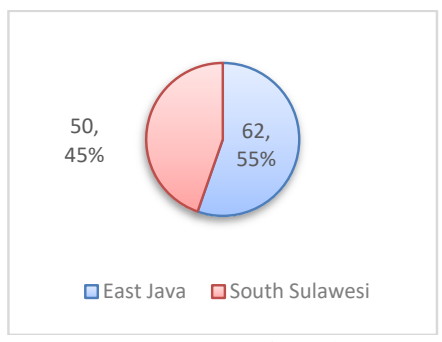

Company location

Fig. 3. Distribution of Company Characteristics

Based on the data in Fig. 3, of the 112 sample companies, 88 units $(78.57 \%)$ were Limited Liability Companies (PT), and the rest were limited companies (CV). Therefore, the total number of workers in the company is $51-100$ people (44.64\%) and over 100 people $(30.36 \%)$. Then, it can also be seen that the location of this research sample came from two regions, namely East Java, as much as $62(55.36 \%)$, and South Sulawesi, as much as 50 (44.64\%). Furthermore, descriptions of research indicators and variables were based on the mean value.

Table 2

Description of Indicators and Variables

\begin{tabular}{|c|c|c|c|c|}
\hline Variables & Indicator & Average (mean) & Std. Deviation & Description \\
\hline \multirow{5}{*}{ Information technology } & $\mathrm{X} 1.1$ & 3.98 & 0.794 & Good \\
\hline & $\mathrm{X} 1.2$ & 3.62 & 0.699 & Good \\
\hline & $\mathrm{X} 1.3$ & 3.79 & 0.737 & Good \\
\hline & $\mathrm{X} 1.4$ & 3,83 & 0.793 & Good \\
\hline & $\mathrm{X} 1.5$ & 3.85 & 0.738 & Good \\
\hline Average - X1 & & 3.81 & & Good \\
\hline \multirow{5}{*}{ Supply chain performance } & Y1.1 & 4.12 & 0,673 & Good \\
\hline & $\mathrm{Y} 1.2$ & 3.76 & 0,762 & Good \\
\hline & Y 1.3 & 3.75 & 0.765 & Good \\
\hline & Y1.4 & 3.85 & 0.75 & Good \\
\hline & Y1.5 & 3.81 & 0.717 & Good \\
\hline Average - Y1 & & 3.85 & & Good \\
\hline \multirow{5}{*}{ Company competitiveness } & Y2.1 & 3.79 & 0.728 & Good \\
\hline & Y 2.2 & 3.92 & 0.699 & Good \\
\hline & Y2.3 & 3.82 & 0.726 & Good \\
\hline & Y 2.4 & 3.8 & 0.655 & Good \\
\hline & Y2.5 & 3.64 & 0.708 & Good \\
\hline Average $-\mathrm{Y} 2$ & & 3.79 & & Good \\
\hline
\end{tabular}

Variable information technology is related to the level of adoption and implementation of information technology in its operational activities and relationships with suppliers and consumers. This variable was measured through 5 (five) indicators, namely: (1) Management intensively encourages the use of computer-based systems in all operational activities of the company - X1.1; (2) Management in a planned manner encourages the use of EDI (electronic data interchange) in enhancing its relationship with its suppliers (suppliers) - X1.2; (3) Management in a planned manner encouraging the use of EDI (electronic data interchange) in enhancing its relationship with its customers (distributors/customers) - X1.3; (4) Management intensively encourages the use of DSS (Decision Support System) in making strategic company decisions - X1.4; (5) Management intensively uses information technology to create efficiency\& effectiveness in the company's business activities - X1.5. Variable supply chain performance is related to the level of performance achieved by a company's supply chain system built by each company with its supplier partners and consumers. This variable is measured through 5 (five) indicators, namely: (1) Management consistently prioritizes the level of reliability of the flow of goods, money, and information in the supply chain system - Y1.1; (2) Management always prioritizes flexibility in exchanging activities of goods, money and information with all members along the supply chain - Y1.2; (3) Managementcontinuously optimizes the utility of its supply chain system to create efficiency and value for all members of the supply chain - Y1.3; (4) An improved supply chain system will result in efficient exchange costs and more value for all members of the supply chain - Y1.4; and (5) Management always prioritizes responsiveness in exchanging goods, money and information with all members along the supply chain - Y1.5. Company 
competitiveness is the accumulation of organizational resource capabilities thatare used in improving the position of a company in a competitive environment. This variable ismeasured through 5 (five) indicators, namely: (1) The company constantly carries out operational activities at a more efficient cost than competitors - Y2.1; (2) The company alwaysoffers products that have a higher quality design compared to competitors - Y2.2; (3) The company is able to increase or decrease the level of production quickly in anticipation of changes in market demand - Y2.3; (4) The company is always consistent in providing fast product delivery to consumers/customers - Y2.4; and (5) The company continually innovates its products consistently in accordance with the needs and desires of customers - Y2.5. The results of descriptive statistical analysis of the complete research indicators and variables can be seen in Table 2. The data in Table 3 shows that the adoption and implementation of information technologyare included in the Good category with an average value of 3.81. Of all the indicators used to measure information technology variables, indicator X1.1, the intensive use of computer-basedsystems, got the highest average value (3.98) compared to other indicators in these variables. Meanwhile, the level of supply chain performance is also included in the Good category with an average value of 3.85. Of all the indicators used to measure the supply chain performance variable, the Y1.1 indicator, the company's consistency in prioritizing the level ofproduct reliability, got the highest average value (4.12) compared to other indicators. In addition, it was also found that company competitiveness was included in the Good category with an average value of 3.79. Of all the indicators used to measure the company variable competitiveness, the Y2.2 indicator, the company consistently offers quality products comparedto competitors, getting the highest average (3.92) compared to other indicators. Based on theseresults, it can be concluded that the adoption and implementation of information technology inthe manufacturing industry, supply chain performance and company competitiveness areincluded in the Good category range $(3.40-4.20)$.

\subsection{Confirmatory factor analysis}

This study uses confirmatory factor analysis to ensure the level of validity and reliabilityof internal constructs. An indicator can be said to be valid if it has a loading factor value greaterthan 0.30 (Sugiyono, 2018). In addition, through this analysis, the dominant indicators in forming a research construct or variable. The complete confirmatory analysis results can be seen in the Table 3.

Table 3

The results of CFA analysis

\begin{tabular}{|c|c|c|c|c|}
\hline Variable & Indicator & Loading Factor & GFI & Description \\
\hline \multirow{5}{*}{ Information technology } & $\mathrm{X} 1.1$ & 0.77 & \multirow{5}{*}{0.979} & \multirow{5}{*}{ Valid and unidimensional } \\
\hline & $\mathrm{X} 1.2$ & 0.581 & & \\
\hline & $\mathrm{X} 1.3$ & 0.774 & & \\
\hline & $\mathrm{X} 1.4$ & 0.802 & & \\
\hline & $\mathrm{X} 1.5$ & 0.572 & & \\
\hline \multirow{5}{*}{ Supply chain performance } & Y1.1 & 0.474 & \multirow{5}{*}{0.988} & \multirow{5}{*}{ Valid and unidimensional } \\
\hline & Y1.2 & 0.768 & & \\
\hline & Y1.3 & 0.669 & & \\
\hline & Y1.4 & 0.702 & & \\
\hline & Y1.5 & 0.656 & & \\
\hline \multirow{5}{*}{ Company competitiveness } & Y2.1 & 0.706 & \multirow{5}{*}{0.98} & \multirow{5}{*}{ Valid and unidimensional } \\
\hline & Y 2.2 & 0.685 & & \\
\hline & Y 2.3 & 0.61 & & \\
\hline & Y 2.4 & 0.743 & & \\
\hline & Y2.5 & 0.776 & & \\
\hline
\end{tabular}

Based on the results of the analysis in Table 3, it is known that the variable or informationtechnology construct has a goodness of fit index (GFI) value that is greater than the standard value $(0.979>0.90)$, and the loading factor value of each indicator is more significant than 0.30.This shows that the construct formed has a Good suitability index, and all these indicators havethe exact dimensions (unidimensional). This value is said to be valid and reliable in explaininglatent variables. The loading factor value reflects the level of importance of an indicator to thelatent variable it forms. Therefore, the dominant indicator that shapes and reflects the constructof information technology is the X1.4 indicator, namely, management intensively encourages the use of DSS (Decision Support System) in making company strategic decisions with a value of 0.802 . The results of the confirmatory factor analysis of variable information technology infull can be seen in Fig. 4. The analysis results also show that the variable or supply chain performance construct hasa goodness of fit index (GFI) value that is greater than the standard value $(0.988>0.90)$, and the loading factor value of each indicator is more significant than 0.30 . This shows that the constructs formed have a Good suitability index, and all these indicators have the same dimension (unidimensional), which can be said to be valid and reliable in explaining latent variables. Furthermore, the loading factor value reflects the level of importance of an indicatorto the latent variable it forms. Therefore, the dominant indicator that shapes and reflects the construct of supply chain performance is indicator Y1.2, namely, management always prioritizes flexibility in business activities with a value of 0.768. The complete results of the confirmatory factor analysis of the variable supply chain performance can be seen in Fig. 5. 


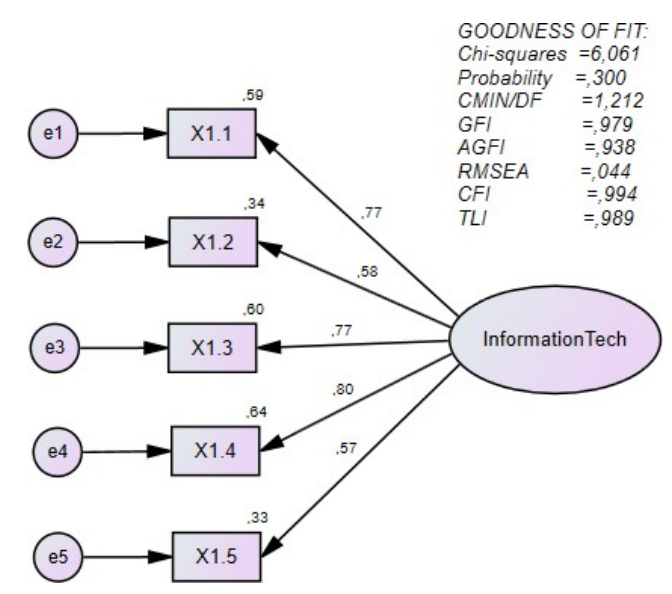

Fig. 4. CFA Results - Variable Information technology

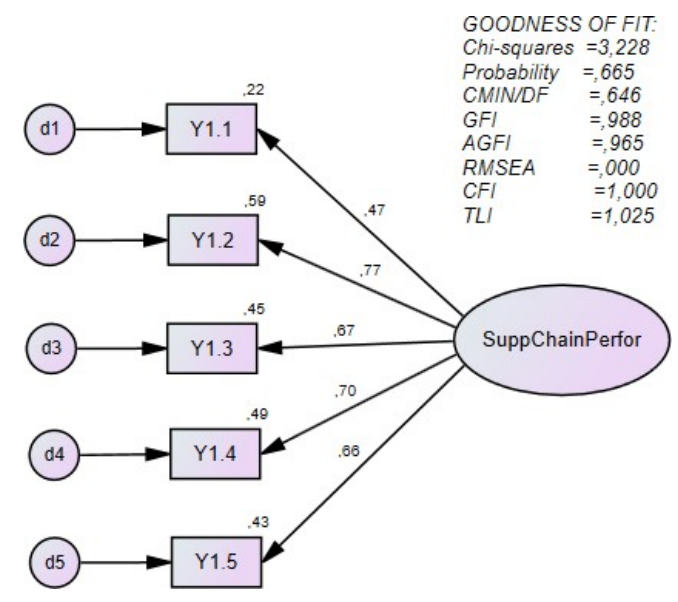

Fig. 5. CFA Results - Variable Supply chain performance

Furthermore, it can also be seen that the variable or company competitiveness construct has a goodness of fit index (GFI) value that is greater than the standard value $(0.980>0.90)$, and the loading factor value of each indicator is more significant than 0.30 . This shows that theconstruct formed has a Good suitability index, and all these indicators have the same dimension (one-dimensionality) and can be said to be valid and reliable in explaining latent variables. Theloading factor value reflects the level of importance of an indicator to the latent variable it forms. Therefore, the dominant indicator that shapes and reflects the construct of company competitiveness is the Y2.5 indicator, namely, the company always innovates its products consistently according to customer needs and desires, with a value of 0.776 . The results of the complete confirmatory factor analysis of company variable competitiveness can be seen in Fig. 6.

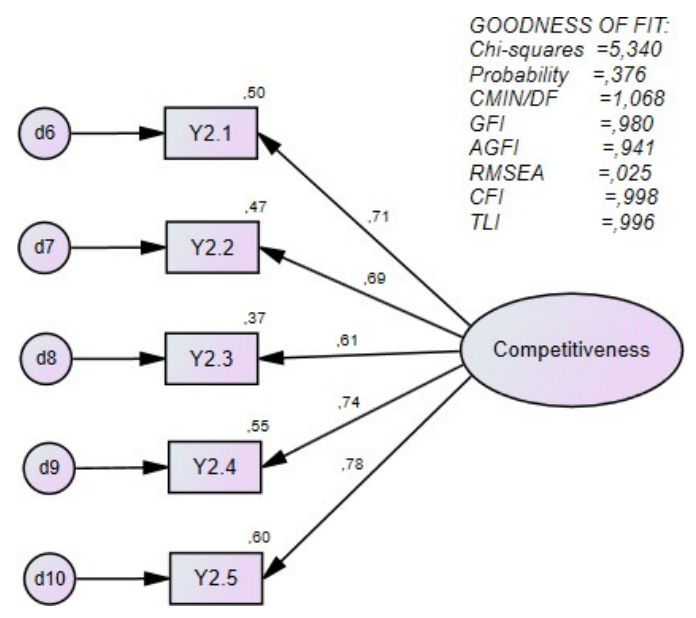

Fig. 6. CFA Results - Variable Company competitiveness

Furthermore, this study uses structural equation modelling (SEM) analysis to test the research hypothesis based on field data. SEM analysis begins with a model fit test using severalessential criteria such as Chi-Square, CMIN / DF, GFI, RMSEA, CFI, and TLI. A model is saidto be Good in accordance with the parsimony theory if it meets at least one standard criterion (Ferdinand, 2002; Hair et al., 2014). The complete model fit test results are presented in Table 4.

Table 4

The goodness of fit model test results

\begin{tabular}{llll}
\hline \multicolumn{1}{c}{ Criteria } & Cut off value & Result & Description \\
\hline Chi-Square & expected small & 114.230 & Marginal \\
CMIN/DF & $\leq 2.00$ & 1.313 & Good \\
GFI & $\geq 0.90$ & 0.884 & Marginal \\
AGFI & $\geq 0.90$ & 0.840 & Marginal \\
RMSEA & $\leq 0.08$ & 0.053 & Good \\
CFI & $\geq 0.94$ & 0.957 & Good \\
TLI & $\geq 0.94$ & 0.948 & Good \\
\hline
\end{tabular}


Based on the test results, it can be concluded that the analysed model has met the requirements of the Good model. Four criteria have met the minimum score requirements, namely CMIN / DF, RMSEA, CFI, and TLI. Meanwhile, the other three criteria, namely Chi- Square, GFI, and AGFI, have not met the standard value. However, this model has met the requirements of the Good model in accordance with the parsimony theory principle so that theresults of the analysis can be used further to test the research hypothesis. The complete hypothesis testing results can be seen in Table 5.

Table 5

Research hypothesis testing results

\begin{tabular}{lcccc}
\hline \multicolumn{1}{c}{ Hypotheses } & Estimate & $\begin{array}{c}\text { Critical } \\
\text { Ratio (CR.) }\end{array}$ & Prob. & Description \\
\hline $\begin{array}{l}\text { Information technology } \rightarrow \\
\text { Supply chain performance }\end{array}$ & 0.457 & 3.181 & 0.001 & $\begin{array}{c}\text { Significant; } \\
\text { H1 accepted }\end{array}$ \\
$\begin{array}{l}\text { Information technology } \rightarrow \\
\text { Company competitiveness }\end{array}$ & 0.260 & 2.587 & 0.010 & Significant; \\
$\begin{array}{l}\text { Supply chain performance } \rightarrow \\
\text { Company competitiveness }\end{array}$ & 0.685 & 3.855 & 0.000 & H2 accepted \\
$\begin{array}{l}\text { Information technology } \rightarrow \text { Supply chain performance } \\
\rightarrow \text { Company competitiveness }\end{array}$ & & & & H3 accepted \\
\hline
\end{tabular}

The data in the table above provides all data and information related to the results oftesting the research hypothesis.

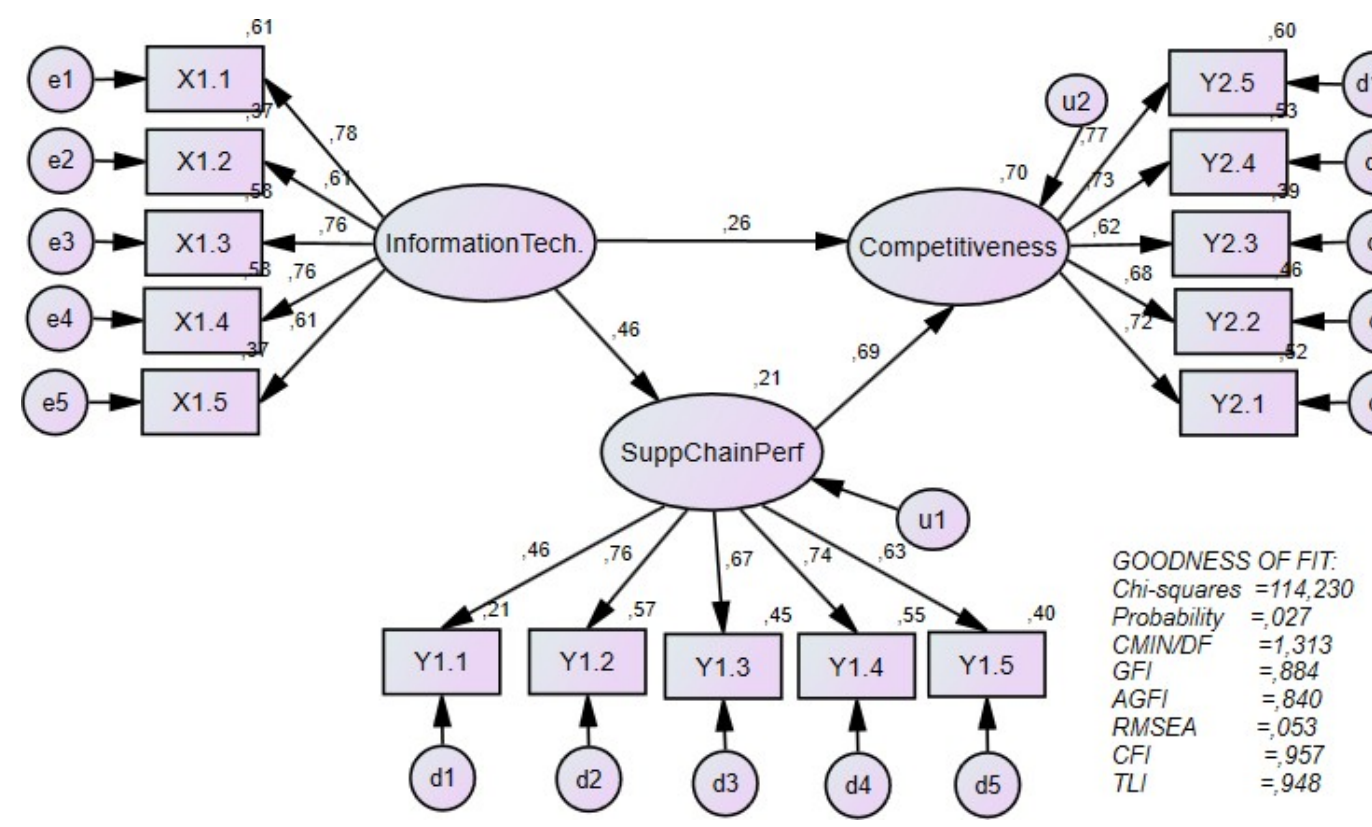

Fig. 7. Empirical Research Model

Fig. 7 is an empirical research model that illustrates the results of the analysis of the direct effect of variable information technology on the company's supply chain performance and competitiveness. In addition, this empirical model also illustrates the indirect effect of variableinformation technology on company competitiveness through the mediating role of the variablesupply chain performance.

\section{Discussion}

The direct effect of variable information technology on supply chain performance can be seen from the critical ratio value, which is greater than the t-table value (3.181>1.960), and the probability value (prob.) Which is smaller than the standard $\alpha$ value $(0.001<0.05)$. These results indicate that Hypothesis-1, namely, the better the adoption and implementation of information technology in the company, the better the supply chain performance is considered proven or supported by facts. Then, the direction of influence, which has a positive value (0.457), indicates that an increase in the variable information technology score will increase the supply chain performance score. The results of this study are consistent with the findings of Bayraktar et al., (2009) that a better organizational information system has a positive effect on supply chain performance. The use of information technology applications increases the company's responsiveness to customer requests (Iyer, 2011; Huo et al., 2016; Imran et al., 2019). Information technology applications such as electronic data interchange (EDI) can increase a company's flexibility in dealing with consumer demand changes and dynamics (Rashed et al., 2010). Furthermore, the direct 
effect of variable information technology on company competitiveness can be seen from the critical ratio value, which is greater than the t-table value $(2.587>1.960)$, and the probability value (prob.) Which is smaller than the standard $\alpha$ value $(0.010<0.05)$. These results indicate that Hypothesis-2, namely, the better the adoption and implementation of information technology in the company, the better the company's competitiveness is proven or supported by facts. Furthermore, the direction of influence which has a positive value (0.260), indicates that any increase in the score for the variable information technology will increase the company competitiveness score. The results of the study are in line with Li \& Lin (2006), who found that the use of information technology can increase company competitiveness, especially in the aspect of delivering products to customers on time. Information technology applications such as decision support systems (DSS) and expert systems (ES) can assist management in making decisions quickly and accurately, especially those related to product development and company innovation (Angeles, 2009; Ghobakhloo \& Tang, 2013). The direct effect of the variable supply chain performance on company competitiveness can be seen from the critical ratio value, which is greater than the t-table value (3.855 $>1.960)$, and the probability value (prob.) Which is smaller than the standard $\alpha$ value $(0.000<0.05)$. These results indicate that Hypothesis-3, namely, the better the supply chain performance, the better the company competitiveness, is said to be proven or supported by facts. Then, the direction of influence which has a positive value $(0.685)$, indicates that any increase in the variable supply chain performance score will increase the company competitiveness score. In general, the production costs of retail products set by manufacturing companies in Indonesia are relatively more expensive compared to neighboring countries such as Thailand, Vietnam, and China. This is partly due to high logistics costs and relatively slow delivery of products to consumers. Therefore, management's attention to supply chain performance is very important to improve their company's competitiveness. These findings are in line with the results of research by Akyuz \& Erkan (2010) and de Vass et al., (2018), who concluded that improvement in supply chain performance is one of the important components to increase company competitiveness. The results of the analysis also show that information technology can also increase company competitiveness through the mediating role of the variable supply chain performance. The value of the indirect effect of variable information technology on company competitiveness is 0.313 . Therefore, Hypothesis-4, namely information technology, can increase company competitiveness through the mediating role of variable supply chain performance, proven or supported by facts. This study indicates that the adoption of information technology can increase company competitiveness in two ways, namely (1) directly to company competitiveness and (2) indirectly through improving supply chain performance. The findings of this study are consistent with the opinion of Chopra \& Meindl, 2007 that the use of information technology supports the development of supply chain performance and company competitiveness. An effective supply chain is characterized by the rapid flow of information, money and products moving along the supply chain system. In addition, a properly managed supply chain system will be able to reduce operational costs and increase company benefits and value.

\section{Conclusion}

This study has confirmed four hypotheses which were formulated based on a conceptual model that was built through empirical data. The better the adoption and implementation of information technology in the company, the better the supply chain performance and company competitiveness. The better the supply chain performance, the better the company competitiveness. The results of the analysis also show that information technology can also increase company competitiveness through the mediating role of the variable supply chain performance. The adoption of information technology can increase company competitiveness directly and indirectly by improving supply chain performance. In addition, it was found that supply chain performance contributed a more significant influence on company competitiveness than information technology.

\section{Practical and Theoretical implications}

The results of this study provide essential information for manufacturing company management in formulating strategic programs and relevant activities that encourage the adoption and use of various types of information technology such as CBIS (computer-based information system), EDI (electronic data interchange), DSS (decision support system), and a variety of other information technology in internal company business activities as well as to improve company relationships with company partners (suppliers, manufacturers, distributors, consumers) in the context of the supply chain system. In addition, the findings of this study have implications for increasingly diverse strategic choices for company management in improving the competitiveness and performance of their companies, especially in the manufacturing sector. The findings of this study also have implications for the variety of reference sources for scientific discussions that take themes/topics/issues of company competitiveness, supply chain management, and the role of information technology in improving company performance and competitiveness in the context of global competition, especially in the manufacturing industry.

\section{Limitation and future research}

This study has two limitations. First, related to the object of study, namely the manufacturing sector only. Therefore, future study has to consider other sectors such as the service sector and trade sector as objects of study. Second, this study only included supply chain performance variables as mediator variables. However, there are several other mediator variables that can be included in the further research models such as innovation, total quality management, and business strategy. 


\section{References}

Akyuz, G., \& Erkan, T. (2010). Supply chain performance measurement: A literature review. International Journal of Production Research, 48(17).

Angeles, R. (2009). Anticipated IT infrastructure and supply chain integration capabilities for RFID and their associated deployment outcomes. International Journal of Information Management, 29(3), 219-231. https://doi.org/10.1016/j.ijinfomgt.2008.09.001

Basheer, M., Siam, M., Awn, A., \& Hassan, S. (2019). Exploring the role of TQM and supply chain practices for firm supply performance in the presence of information technology capabilities and supply chain technology adoption: A case of textile firms in Pakistan. Uncertain Supply Chain Management, 7(2), 275-288.

Bayraktar, E., Demirbag, M., Koh, S., Tatoglu, E., \& Zaim, H. (2009). A causal analysis of theimpact of information systems and supply chain management practices on operational performance: Evidence from manufacturing SMEs in Turkey. International Journal of Production Economics, 122(1). https://doi.org/10.1016/j.ijpe.2009.05.011

Chopra, S., \& Meindl, P. (2007). Supply Chain Management. Strategy, Planning \& Operation. USA: Pearson Education. https://doi.org/10.1007/978-3-8349-9320-5_22

de Vass, T., Shee, H., \& Miah, S. (2018). The effect of "Internet of Things" on supply chain integration and performance: An organizational capability perspective. Australasian Journal of Information Systems, 22. https://doi.org/10.3127/ajis.v22i0.1734

Ferdinand, A. (2002). Structural equation modeling in management research. Semarang:Fakultas Ekonomi UNDIP.

Ghobakhloo, M., \& Tang, S. (2013). The role of owner/manager in adoption of electronic commerce in small businesses: The case of developing countries. Journal of Small Business and Enterprise Development, 20(4), 754-787. https://doi.org/10.1108/JSBED-12-2011-0037

Gunasekaran, A., Patel, C., \& McGaughey, R. E. (2004). A framework for supply chain performance measurement. International Journal of Production Economics, 87(3), 333-347.

Hair, J., Black, W., Babin, B., \& Anderson, R. (2014). Multivariate Data Analysis Seventh Edition. In Pearson New International. https://doi.org/10.1007/978-3-319-01517-0_3

Heizer, J., Render, B., \& Munson, C. (2017). Operations Management: Sustainability \& SupplyChain Management 12th edition. In Corporate finance.

Huo, B., Ye, Y., Zhao, X., \& Shou, Y. (2016). The impact of human capital on supply chain integration and competitive performance. International Journal of Production Economics, 178, 132-143.

Imran, M., Hamid, S. N. B. A., Aziz, A., \& Hameed, W. (2019). The contributing factors towards e-logistic customer satisfaction: a mediating role of information Technology. Uncertain Supply Chain Management, 7(1), 63-72.

Iyer, K. (2011). Demand chain collaboration and operational performance: Role of IT analyticcapability and environmental uncertainty. Journal of Business and Industrial Marketing,26(2), 81-91. https://doi.org/10.1108/08858621111112267.

Koçoğlu, İ., İmamoğlu, S. Z., İnce, H., \& Keskin, H. (2011). The effect of supply chain integration on information sharing: Enhancing the supply chain performance. Procedia-Social and Behavioral Sciences, 24, 1630-1649

Kumar, V., Chibuzo, E. N., Garza-Reyes, J. A., Kumari, A., Rocha-Lona, L., \& Lopez-Torres, G. C. (2017). The impact of supply chain integration on performance: Evidence from the UK food sector. Procedia Manufacturing, 11, 814-821.

Lakhal, L. (2009). Impact of quality on competitive advantage and organizational performance. Journal of the Operational Research Society, 60(5), 637-645.

Lee, M. K., \& Turban, E. (2001). A trust model for consumer internet shopping. International Journal of Electronic Commerce, 6(1), 75-91.

Li, G., Yang, H., Sun, L., \& Sohal, A. (2009). The impact of IT implementation on supply chainintegration and performance. International Journal of Production Economics, 120(1). https://doi.org/10.1016/j.ijpe.2008.07.017

Li, S., \& Lin, B. (2006). Accessing information sharing and information quality in supply chain management. Decision Support Systems, 42(3), 1641-1656.

Li, S., Ragu-Nathan, B., Ragu-Nathan, T. S., \& Rao, S. S. (2006). The impact of supply chain management practices on competitive advantage and organizational performance. Omega, 34(2), 107-124.

Lin, Y., Wang, Y., \& Yu, C. (2010). Investigating the drivers of the innovation in channel integration and supply chain performance: A strategy orientated perspective. International Journal of Production Economics, 127(2). https://doi.org/10.1016/j.ijpe.2009.08.009

Munir, M., Jajja, M., Chatha, K., \& Farooq, S. (2020). Supply chain risk management and operational performance: The enabling role of supply chain integration. International Journal of Production Economics. https://doi.org/10.1016/j.ijpe.2020.107667

Munizu, M. (2021). Total Quality Management and Organizational Competitiveness. 1stedition. Makassar: UPT Unhas Press.

Pono, M., \& Munizu, M. (2021). The role of company competitiveness as mediation variable the impact of supply chain practices on operational performance. Uncertain Supply ChainManagement, 9(1), 125-132.

Porter, M. (2011). Competitive advantage of nations: creating and sustaining superior performance. simon and schuster.

Prajogo, D., \& Olhager, J. (2012). Supply chain integration and performance: The effects of long-term relationships, information technology and sharing, and logistics integration. International Journal of Production Economics, 135(1). https://doi.org/10.1016/j.ijpe.2011.09.001 
Pujawan, I., \& Erawan, M. (2010). Supply Chain Management. 2nd edition. Surabaya: Guna Widya Press.

Qrunfleh, S., \& Tarafdar, M. (2014). Supply chain information systems strategy: Impacts on supply chain performance and firm performance. International Journal of Production Economics, 147, 340-350.

Rashed, C., Azeem, A., \& Halim, Z. (2010). Effect of Information and Knowledge Sharing onSupply Chain Performance: A Survey Based Approach. Journal of Operations and Supply Chain Management, 3(2). https://doi.org/10.12660/joscmv3n2p61-77

Simchi-Levi, D., Kaminsky, P., Simchi-Levi, E., \& Shankar, R. (2008). Designing and Managing the Supply Chain: Concepts, Strategies and Case Studies. Tata McGraw-Hill Education.

Sohn, Y. Y., \& Yang, H. W. (2006). Information Technology, Corporate Performance and Firm Size. In The Economics of Online Markets and ICT Networks (pp. 203-214). Physica-Verlag HD

Sugiyono. (2018). Business Research Method. Bandung: Alfabeta Press.

Vanpoucke, E., Vereecke, A., \& Muylle, S. (2017). Leveraging the impact of supply chain integration through information technology. International Journal of Operations and Production Management, 37(4), 510-530.

Wang, G., Gunasekaran, A., Ngai, E. W., \& Papadopoulos, T. (2016). Big data analytics in logistics and supply chain management: Certain investigations for research and applications. International Journal of Production Economics, 176 , 98-110.

Yusuf, R., \& Shehu, A. (2017). The review of supply chain management systems and firm performance. International Journal of Management Research and Reviews, 7(2), 113. 
(C) 2021 by the authors; licensee Growing Science, Canada. This is an open access article distributed under the terms and conditions of the Creative Commons Attribution (CCBY) license (http://creativecommons.org/licenses/by/4.0/). 